\title{
Niche differentiation between sympatric alien aquatic crustaceans: An isotopic evidence
}

\author{
Karl-Otto Rothhaupt, Almut J. Hanselmann, Elizabeth Yohannes* \\ Limnological Institute, University of Konstanz, Mainaustrasse 252, D-78464 Konstanz, Germany
}

\begin{abstract}
Among the mechanisms that allow competing species to coexist are resource partitioning and dietary segregation. The current study uses multiple stable isotopes, carbon $\left(\delta^{13} \mathrm{C}\right)$, nitrogen $\left(\delta^{15} \mathrm{~N}\right)$ and sulphur $\left(\delta^{34} \mathrm{~S}\right)$, to test the hypothesis that dietary segregation in cohabiting invasive mysids (Limnomysis benedeni and Katamysis warpachowskyi) and gammarids (Dikerogammarus villosus and Gammarus roeselii) will be reflected by differences in isotope values. Furthermore, IsoError mixing models were used to estimate the relative contributions of periphyton and seston to the invaders' diets. Whole tissue $\delta^{13} \mathrm{C}, \delta^{15} \mathrm{~N}$ and $\delta^{34} \mathrm{~S}$ analysis in L. benedeni and $K$. warpachowskyi imply that these sympatric, non-native mysids maintain differentiated feeding niches or resource partitioning by feeding on distinct components of the available food resources (predominantly seston by L. benedeni and periphyton by $K$. warpachowskyi). By contrast, the gammarids D. villosus ('killer shrimp') and G. roeselii exhibited no significant difference in $\delta^{13} \mathrm{C}$ and $\delta^{15} \mathrm{~N}$, indicating a considerable overlap between the dietary sources of these sympatric invaders. Feeding niche differentiation, irrespective of season or the nature of habitat invaded (lake or river), might facilitate the coexistence of invasive mysids in their 'new' environment by minimizing direct resource competition. The mutual interaction by the invasive gammarids, coupled with voracious behavior, could assist their success at co-invasion with serious implications for local biodiversity including the potential extinction of native species.
\end{abstract}

\section{Zusammenfassung}

Ressourcenteilung (unterschiedliche Nischenweite) und Nahrungssegregation (Nahrungsbreite) sind Mechanismen, die Koexistenz bei konkurrierenden Arten ermöglichen.

Wir testeten an Hand der stabilen Isotope Kohlenstoff $\left(\delta^{13} \mathrm{C}\right)$ Stickstoff $\left(\delta^{15} \mathrm{~N}\right)$ und Schwefel $\left(\delta^{34} \mathrm{~S}\right)$ die Hypothese einer Nahrungssegregation bei syntop lebenden invasiven Mysiden (Schwebgarnelen) und Gammariden (Flohkrebsen) die sich in konsistenten Unterschieden in den Mustern der stabilen Isotope widerspiegeln sollte. Wir analysierten Proben von 5 Standorten entlang des Bodensees und Rheins in Österreich und Deutschland, um auf eine Konsistenz der zwischenartlichen Isotopen-Muster in unterschiedlichen Habitaten schliessen zu können. Hierbei schätzten wir den relativen Anteil verschiedener Periphytonund Sestonnahrungsquellen der Mysiden mit Hilfe eines IsoError mixing models. Die sympatrischen, nicht einheimischen Mysiden Limnomysis benedeni und Katamysis warpachowskyi unterschieden sich in $\delta^{13} \mathrm{C}, \delta^{15} \mathrm{~N}$ and $\delta^{34} \mathrm{~S}$, wiesen jedoch ähnliche Muster auf. Dies deutet auf unterschiedliche Nahrungsnischen und eine habitatspezifische, aber ähnliche Ressourcenaufteilung hin, indem beide Arten verschiedene Komponenten der verfügbaren Futterquellen, hauptsächlich aus dem Seston,

\footnotetext{
*Corresponding author. Tel.: +49 0753188 2970; fax: +4907531 883533.

E-mail address: Elizabeth.Yohannes@uni-konstanz.de (E. Yohannes).
} 
nutzen. Die Gammariden Dikerogammarus villosus ("killer shrimp") und Gammarus roeselii zeigten keine signifikanten $\delta^{13} \mathrm{C}$ und $\delta^{15} \mathrm{~N}$ Unterschiede, sodass eine beträchtliche Überlappung der Nahrungsnischen dieser sympatrischen Invasoren vorliegt. Unsere Daten zeigen zudem, dass beide Gammariden ihre Ernährungweise plastisch umstellen können und so auf veränderte Habitatbedingungen und/oder Rivalen- bzw. Räuberdruck reagieren können. Die gleichsinnigen Interaktionen der invasiven Gammariden-Arten, gepaart mit ihrer Gefrässigkeit, würden eine erfolgreiche Invasion erleichtern, die negative Auswirkungen auf die lokale Biodiversität bis hin zum Aussterben einheimischer Arten haben könnte. (c) 2014 Gesellschaft für Ökologie. Published by Elsevier GmbH. All rights reserved.

Keywords: Stable isotopes; Carbon $\left(\delta^{13} \mathrm{C}\right)$; Nitrogen $\left(\delta^{15} \mathrm{~N}\right)$; Sulphur $\left(\delta^{34} \mathrm{~S}\right)$; Lake Constance; Limnomysis benedeni; Katamysis warpachowskyi; Dikerogammarus villosus; Gammarus roeselii

\section{Introduction}

Alien or invasive species often benefit from specific traits that equip them to outcompete native species in their 'new' environment. Usually, competition between alien and native species would be expected to center on rates of growth and reproduction, yet in other cases invaders might interact with other non-native species directly. Invasive species may influence the evolutionary ecology of natives by competitive exclusion or extinction, predation, niche displacement, hybridization or introgression. Likewise, the ecology and behavior of the invaders may also be altered by competition with native or non-native species and in response to environmental conditions prevailing in the invaded habitat (reviewed by Mooney \& Cleland 2001).

There are several mechanisms that enable competing species to coexist (Chesson 2000). These include temporal segregation in periods of high resource use (Kotler, Brown, \& Subach 1993), resource partitioning based on morphology (Leyequién, de Boer, \& Cleef 2007) and dietary segregation associated with differences in feeding behavior (Page, McKenzie, \& Goldsworthy 2005).

Alien invaders must be able to acquire food resources in heterogeneous and unpredictable habitats, and their feeding behavior should be linked to prey abundance and distribution. In order to maximize their success, and in response to the limited predictability of their 'new' environment, individuals of a given invasive species should tend to minimize competition by exhibiting resource partitioning. By implication, increase in population niche width could mean an increase in individual specialization or enhanced species generalization. In this study, we compared isotopic values between four species of freshwater crustacean: Limnomysis benedeni, Katamysis warpachowskyi, Dikerogammarus villosus and Gammarus roeselii, in Lake Constance and the River Rhine (Austria and Germany) at five distinct study sites.

The mysids $L$.benedeni and $K$. warpachowskyi are highly invasive species originating from the Ponto-Caspian region of Eastern Europe (Audzijonyte, Wittmann, Ovcarenko, \& Väinölä 2009), and were first observed in Lake Constance in 2006 and 2009, respectively (Fritz, Nisch, Wittkugel,
\& Mörtl 2006; Hanselmann 2010). Their migration into Western Europe is likely to have taken place via the river systems of the Main-Danube Canal and the River Rhine (Bij De Vaate, Jazdzewski, Ketelaars, Gollasch, \& Van Der Velde 2002). Previous studies on the feeding ecology and lifehistory of $L$. benedeni show that it resides on coarse rocky structures and macrophytes (Gergs, Hanselmann, Eisele, \& Rothhaupt 2008) and filters or grazes on small particles of benthic and pelagic origin (Hanselmann, Gergs, \& Rothhaupt 2011a, 2011b; Hanselmann, Hodapp, \& Rothhaupt 2013). In a recently established population in North-Western Germany, L. benedeni was shown to utilize pelagic carbon sources with omnivorous feeding characteristics (Fink \& Harrod 2013). Although detailed studies on the life-history and ecology of $K$. warpachowskyi in Lake Constance are lacking, like $L$. benedeni it is known to be a benthic feeder on detritus and fine algal particles (Dediu 1966; Gergs et al. 2008).

The gammarid Dikerogammarus villosus also originates from the Ponto-Caspian region and has become invasive across most of the western part of Europe (Kley \& Maier 2005; Gergs \& Rothhaupt 2008). It is one of the most successful invaders in the inland waters of Southern Germany; in the Danube, Main, Rhine and Lake Constance. In Lake Constance, it was first observed in 2002 (in the north-western part of the lake). In 2004, the species has spread over the entire sections the Upper and Lower Lake Constance (Mürle, Becker, \& Rey 2004).

Known as 'the killer shrimp, D. villosus exhibits rapid growth, survives in a wide range of habitats and kills other animals without necessarily feeding on them (e.g., Kinzler, Kley, Mayer, Waloszek, \& Maier 2009). However, it can also be a voracious predator of several macro-invertebrates, including other gammarids and small fish, fish eggs and larvae, resulting local extinction of native species and reduced biodiversity (e.g., Dick \& Platvoet 2000; Kinzler \& Maier 2003; MacNeil et al. 2003; MacNeil, Dick, Platvoet, \& Briffa 2011). G. roeselii, a freshwater amphipod, is now commonly found across Europe, having spread north from the Balkans via the Danube river system, the species has become established as an alien resident in Central Europe (Grabowski, Bacela, \& Konopacka 2007). At Lake Constance, G. roeselii was first reported by 
Hartmann (1977) as a considerable portion of the gut contents of fishes sampled between 1974 and 1975. A previous monograph on Lake Constance (Kiefer 1972) lists G. fossarum and G. lacustris as gammarid species in the 1950s. Thus, it is likely that $G$. roeselii invaded the lake in the 1960 s or early 1970 s.

The current study aimed to test the hypothesis that the tissues of cohabiting species of invasive mysids (L. benedeni and $K$. warpachowskyi) and gammarids (D. villosus and $G$. roeselii) will exhibit consistent and significant variation in stable isotope values. Observing such differences in all the habitats considered would be clear evidence of resource partitioning. Furthermore, we hypothesized that the purported predacious nature of $D$. villosus would be discernible in relatively higher $\delta^{15} \mathrm{~N}$ values.

Stable isotope analyses using carbon $\left(\delta^{13} \mathrm{C}\right)$, nitrogen $\left(\delta^{15} \mathrm{~N}\right)$ and sulphur $\left(\delta^{34} \mathrm{~S}\right)$ are popular tools for comparative studies of niche widths and trophic positions in different organisms (Bearhop, Adams, Waldron, Fuller, \& Macleod 2004). Because ${ }^{15} \mathrm{~N}$ tends to become enriched by trophic transfer, ratios of nitrogen isotopes $\left({ }^{15} \mathrm{~N}:{ }^{14} \mathrm{~N}\right)$ can be used to index relative trophic levels, and ratios of carbon isotopes $\left({ }^{13} \mathrm{C}:{ }^{12} \mathrm{C}\right)$, are likewise used to identify the sources of basal carbon signatures in freshwater systems (Finlay \& Kendall 2007; Post, 2002). In lakes, pelagic carbon sources are usually characterized by relatively low ${ }^{13} \mathrm{C}:{ }^{12} \mathrm{C}$ ratios as compared to littoral carbon sources (France 1995).

Interpretation of stable isotope ratios is generally based on the observation that there is typically an isotopic difference between the isotope ratios of consumer and diet tissue. Recent stable isotope methodology of sulphur $\left(\delta^{34} S\right)$ values has proved useful to investigating organismal trophic ecology. Experimental studies confirm that, unlike for $\delta^{15} \mathrm{~N}$ and $\delta^{13} \mathrm{C}$, there is little or no $\delta^{34} \mathrm{~S}$ discrimination associated with the incorporation of sulphur containing diet into consumer tissues (e.g. Richards, Fuller, Sponheimer, Robinson, \& Ayliffe 2003).

\section{Materials and methods}

\section{Study sites and methods}

Samples of L. benedeni, K. warpachowskyi, D. villosus and $G$. roeselii were collected from five sites representing two distinct habitats (4 lake sites and 1 river site) Table 1 describes the study sites, years and months of sampling. The littoral habitats of Lake Constance at Site 3 (Immenstaad) and Site 4 (Hagnau) exhibit relatively few signs of human activity and retain coarse-fine gravel embankments. Study sites 1 and 5 (Hard, Austria) are located close to a dam and represent a more anthropogenically modified landscape characterized by large coarse gravel embankments. It was at these two sites that the invasion of the lake by the two non-native mysids was first documented (Hanselmann 2010).

Invertebrate samples were collected by kick sampling in a water depth of ca. $0.56 \mathrm{~m}$, using dip nets (mesh size $200 \mu \mathrm{m}$ ). Invertebrates were kept overnight in filtered lake water over gauze screens to allow gut clearance. Periphyton was obtained by gently removing samples from stones using a brush sampler (Peters, Scheifhacken, Kahlert, \& Rothhaupt 2005). To obtain seston, a Ruttner sampler was used and a sub-sample of approx. $1 \mathrm{~L}$ was filtered through a pre-combusted glassfiber filter (Whatman GF/F). Carbonate from seston and periphyton samples was then removed by acidification of samples in $1 \mathrm{M} \mathrm{HCl}$ (for ca. $2 \mathrm{~h}$ ).

\section{Stable isotope measurements}

Lipids were removed from each homogenized sample by soaking in 2:1 chloroform-methanol solution for $24 \mathrm{~h}$ then rinsing in distilled water before conducting stable isotope analysis. Lipid extraction was necessary because levels of ${ }^{13} \mathrm{C}$ in lipids are depleted relative to whole organism or tissue ${ }^{13} \mathrm{C}$, and variations in the lipid content of animal tissue samples may skew the isotope values (Kling, Fry, \& O'Brien 1992; Peterson \& Fry 1987).

Table 1. Sampling years, months and locations for mysids (L. benedeni and K. warpachowsky) and gammarids (D. villosus and G. roeselii) from Lake Constance and River Rhine.

\begin{tabular}{|c|c|}
\hline Year samples (month) & Site, location (coordinates) \\
\hline \multicolumn{2}{|l|}{2010} \\
\hline Mysids (March) & Site 1: Lake Constance (Hard, Austria $52^{\circ} 80^{\prime} 91^{\prime \prime} \mathrm{N}, 35^{\circ} 29^{\prime} 20^{\prime \prime} \mathrm{E}$ ) \\
\hline Mysids and gammarids (June) & Site 1: Lake Constance (Hard, Austria $52^{\circ} 80^{\prime} 91^{\prime \prime} \mathrm{N}, 35^{\circ} 29^{\prime} 20^{\prime \prime} \mathrm{E}$ ) \\
\hline \multicolumn{2}{|l|}{2011} \\
\hline Mysids and gammarids (June) & $\begin{array}{l}\text { Site 1: Lake Constance (Hard, Austria } 52^{\circ} 80^{\prime} 91^{\prime \prime} \mathrm{N}, 35^{\circ} 29^{\prime} 20^{\prime \prime} \mathrm{E} \text { ) } \\
\text { Site 2: River Rhine (Philippsburg-Rheinsheim } 49^{\circ} 13^{\prime} 59^{\prime \prime} \mathrm{N}, 8^{\circ} 24^{\prime}\end{array}$ \\
\hline \multicolumn{2}{|l|}{2012} \\
\hline $\begin{array}{l}\text { Mysids and gammarids [May (Site 3), June (Site 4) and } \\
\text { July (Site 5)] }\end{array}$ & $\begin{array}{l}\left.\text { Site 3: Lake Constance (Immenstaad } 47^{\circ} 40^{\prime} 00^{\prime \prime} \mathrm{N}, 09^{\circ} 22^{\prime} 00^{\prime \prime} \mathrm{E}\right) \\
\left.\text { Site 4: Lake Constance (Hagnau } 52^{\circ} 81^{\prime} 28^{\prime \prime} \mathrm{N}, 35^{\circ} 24^{\prime} 70^{\prime \prime} \mathrm{E}\right) \\
\text { Site 5: Lake Constance (Hard, Austria } 52^{\circ} 62^{\prime} 43^{\prime \prime} \mathrm{N}, 35^{\circ} 51^{\prime} 36^{\prime \prime} \mathrm{E} \text { ) }\end{array}$ \\
\hline
\end{tabular}




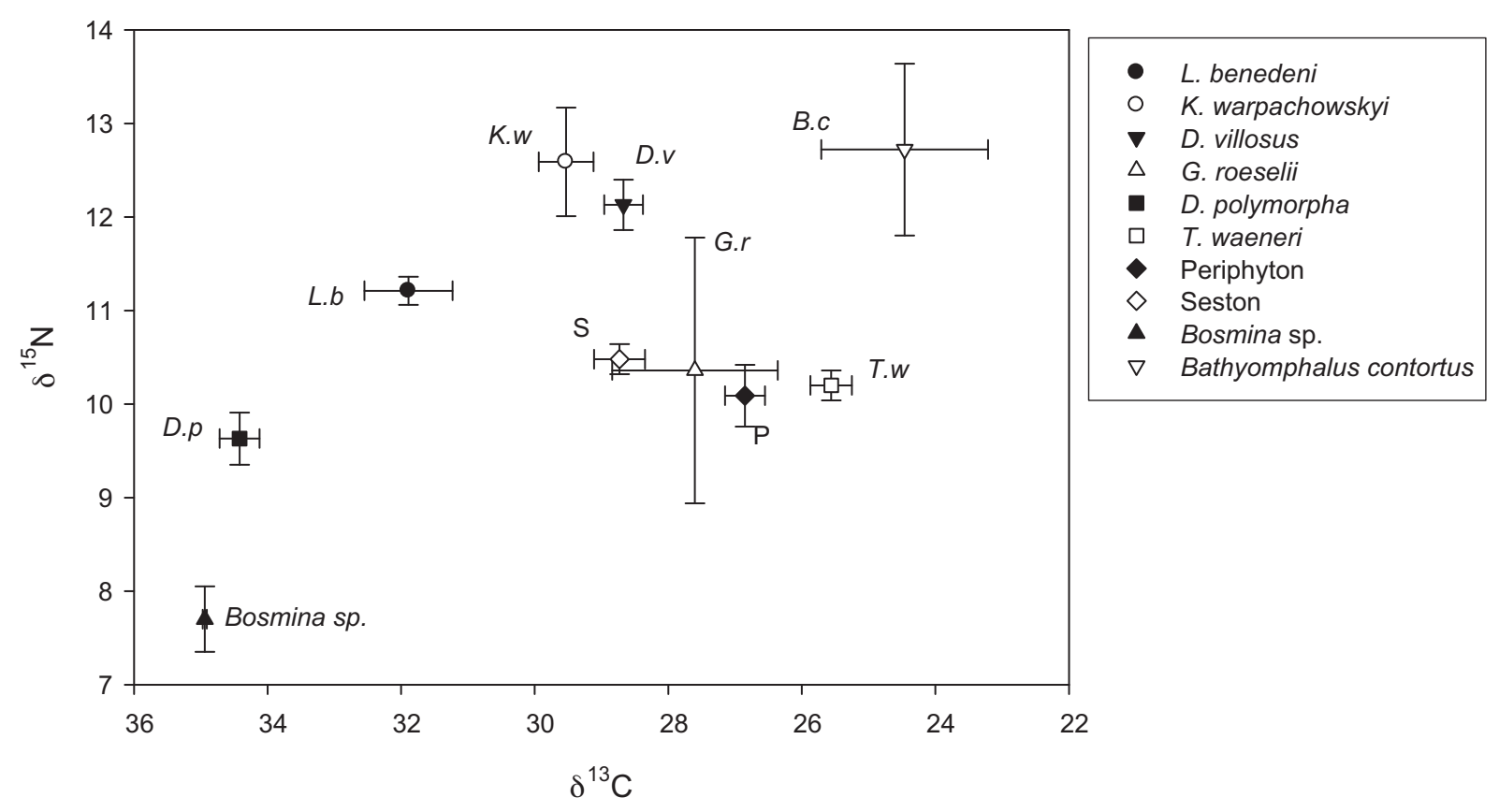

Fig. 1. Mean \pm standard error (SE) of $\delta^{13} \mathrm{C}$ and $\delta^{15} \mathrm{~N}$ values of L. benedeni, K. warpachowskyi, D. villosus and G. roeselii. Dreissena polymorpha, Tinodes waeneri, Periphyton, Seston, Bosmina sp. and Bathyomphalus contortus collected from a single study site in Lake Constance (Site 1) in March 2010.

Dried, powdered samples (ca. $1 \mathrm{mg}$ whole animal tissue, $3 \mathrm{mg}$ for periphyton and seston) were loaded into tin capsules and combusted in a vario Micro cube elemental analyzer (Elementar, Analysen systeme, Germany). The resulting gases were fed via gas chromatography into the inlet of a Micromass (Manchester, UK) Isoprime Isotope Ratio Mass Spectrometer (IRMS). Measurements are reported in $\delta$-notation in parts per thousand deviations (\%o) relative to international standards for carbon (Pee Dee Belemnite, PDB) and nitrogen (atmospheric $\mathrm{N}_{2}$, air, $\mathrm{SO}_{2}$ ), according to the equation:

$\delta(\% o)=1000 \times\left(\frac{R_{\text {sample }}}{R_{\text {standard }}}-1\right)$.

Two sulfanilamides (iso-prime internal standards) and two Casein standards were used for every seven unknowns in sequence. Internal laboratory standards indicated measurement errors (SD) of $\pm 0.05 \%$ ofor $\delta^{13} \mathrm{C}, 0.15 \%$ o for $\delta^{15} \mathrm{~N}$ and $0.05 \%$, for $\delta^{34} \mathrm{~S}$. For each element, inter-species and inter-site differences (and their interaction) were explored applying three separate two-way ANOVAs: for mysids in 2011, and for mysids and gammarids in 2012, separately). For mysids collected in March and June 2010 (Site 1), species and inter-month differences (and their interaction) were explored applying a separate two-way ANOVA.

\section{Dietary isotopic signatures}

Frequently, direct seston samples did not give reliable estimates of pelagic $\delta^{13} \mathrm{C}$ signatures. As exemplified by the $\delta^{13} \mathrm{C}-\delta^{15} \mathrm{~N}$ diagram of the sampling that was conducted in March 2010 (Site 1, Hard), seston $\delta^{13} \mathrm{C}$ values are unrealistically high (Fig. 1). This is most probably due to the fact that in the littoral zone of Lake Constance, wind and ship-wave induced sediment resuspension is a frequent phenomenon that tends to distort seston measurements (Hofmann, Lorke, \& Peeters 2011). To resolve this problem and in order to obtain reliable baseline isotope values for Lake Constance, we evaluated the isotopic signatures of two groups of primary consumers, the first feeding predominantly on autochthonous epilithic material (e.g., periphyton) and the second targeting seston (bioseston and tripton) sources.

The samplings at Site 1 (Hard, Austria), which were conducted in March and July 2010, included organisms that were suitable baseline indicators for both feeding types. In the March 2010 sampling, the filter feeding zebra mussel Dreissena polymorpha was chosen to represent primary consumers relying on biotic or abiotic seston and the trichopteran Tinodes waeneri was used to gauge the isotope values of autochthonous epilithic production at the site. In the July 2010 sampling campaign, the filter-feeding cladoceran Bosmina sp. was chosen to represent seston consumers and the pulmonate gastropod Bathyomphalus contortus as a representative of a biofilm consumer. Application of diettissue discrimination corrections of $-0.5 \%$ yielded corrected $\delta^{13} \mathrm{C}$ values for periphyton and seston. The results were then compared with those obtained for L. benedeni and $K$. warpachowskyi from the same site and the same sampling campaign. 


\section{Mixing models}

In order to estimate the proportional contributions of periphyton and seston food sources to the isotopic tissue composition of $L$. benedeni and $K$. warpachowskyi, the mathematical dietary mixing model IsoError (www.epa. gov/wed/pages/models.htm; accessed 26 June 2013) was applied and isotopic mass balance calculated (Philips 2012; Philips \& Gregg 2003) for one element $\left(\delta^{13} \mathrm{C}\right)$ and two food sources (seston and periphyton).

The mixing model is described by the following equations:

$\delta^{13} C_{\text {con }}=f_{1} \delta^{13} C_{\mathrm{s}}+f_{2} \delta^{13} C_{p}$

$f_{1}=\frac{\delta^{13} C_{\text {con }}-\delta^{13} C_{p}}{\delta^{13} C_{s}-\delta^{13} C_{p}}$

$1=f_{1}+f_{2}$

where $\delta^{13} \mathrm{C}_{\text {con }}=$ elemental isotope value of the consumer as a combination of elements from the two dietary sources (subscripts: $s=$ seston and $p=$ periphyton). Since the two dietary sources were isotopically distinct (varying by ca. $10 \%$ and 9\%o in March and June, respectively), we were confident of the ability of the mixing model to estimate precise dietary proportions.

Clearly, the proportional contributions of periphyton and seston food sources could only be estimated for samplings including suitable indicator organisms. This was only the case for two samplings at Site 1 (Hard, Austria) in 2010, but not for the other sampling campaigns on Lake Constance and the river Rhine. However, assuming that the species investigated exhibit similar dietary habits, we expected that the isotopic niches given by the $\delta^{13} \mathrm{C}, \delta^{15} \mathrm{~N}$ and $\delta^{34} \mathrm{~S}$ values should be qualitatively similar at different sampling sites.

Finally, we measured relative variability in basal carbon sources between invaders, using coefficient of variation (CV) in $\delta^{13} \mathrm{C}$ expressed as percentage. Stable isotopes are well suited to explore species niche width with variance in $\delta$-space among species being a proxy for niche width (Bearhop et al. 2004; Newsome et al. 2009). Since $\delta^{13} \mathrm{C}$ gauges the sources of the basal carbon signature, for this part of the analysis on niche width we focused on $\delta^{13} \mathrm{C}$ values.

\section{Results}

\section{Mysids and gammarids}

As expected, the $\delta^{13} \mathrm{C}, \delta^{15} \mathrm{~N}$ and $\delta^{34} \mathrm{~S}$ values obtained for $L$. benedeni and $K$. warpachowskyi for each sampling year: 2010 (Fig. 1 and Table 2), 2011 and 2012 (Fig. 2 and Table 2)
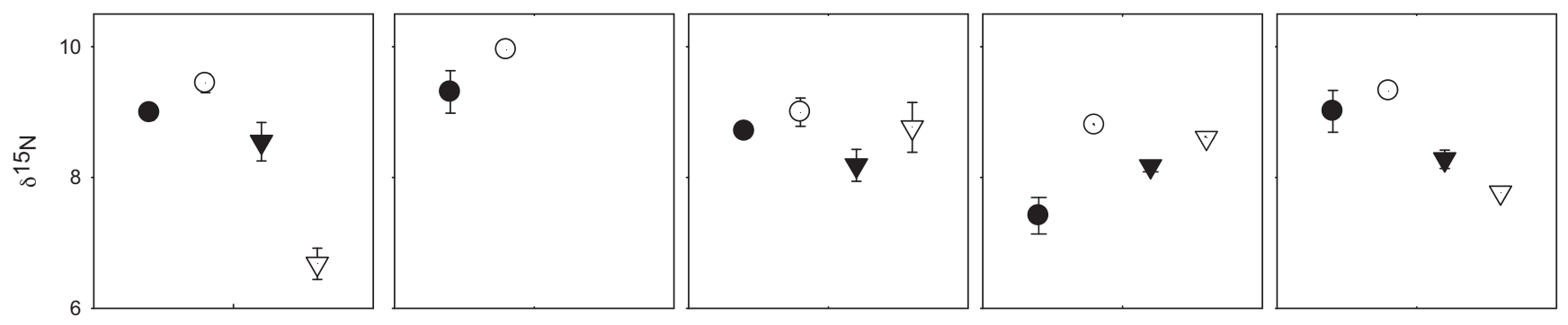

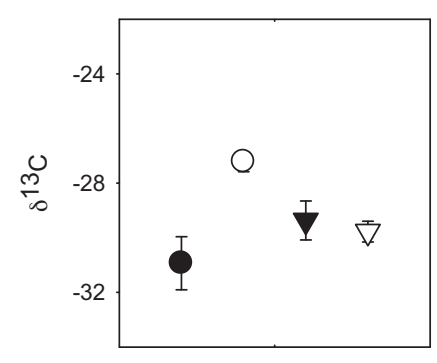

Site 1 Hard, Lake Constance

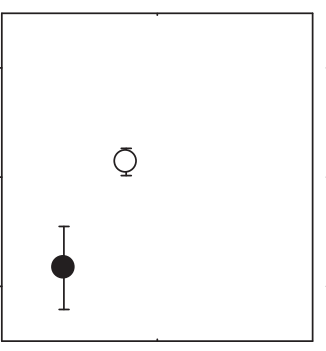

Site 2 River Rhine

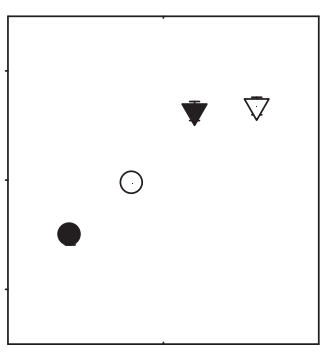

Site 3

Immenstaad, Lake Constance

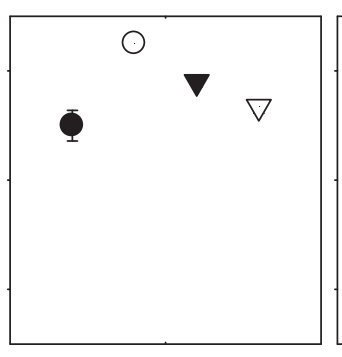

Site 4

Hagnau, Lake Constance

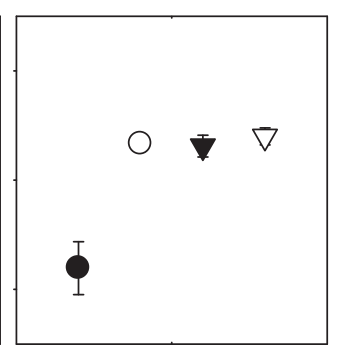

Site 5

Hard, Lake Constance

\begin{tabular}{|ll}
\hline & L. benedeni \\
$\nabla$ & K. warpachowskyi \\
$\nabla$ & D. villous \\
$\nabla$ & G. roeselii
\end{tabular}

Fig. 2. Mean \pm standard error (SE) of $\delta^{13} \mathrm{C}$ and $\delta^{15} \mathrm{~N}$ values of L. benedeni $(\mathbf{\bullet})$, K. warpachowskyi $(\bigcirc)$, D. villosus $(\mathbf{\nabla})$ and G. roeselii $(\square)$ from five study sites in Lake Constance. Site 1 = Lake Constance (Hard); mysids = March 2010, June 2010 and 2011; gammarids = June 2010 and 2011. Site $2=$ River Rhine; mysids = June 2011; gammarids = June 2011. Site 3=Lake Constance (Immenstaad); mysids = May 2012; gammarids $=$ May 2012. Site $4=$ Lake Constance $($ Hagnau $)$; mysids $=$ June 2012; gammarids $=$ June 2012 Site $5=$ Lake Constance $($ Austria $)$ mysids = July 2012; gammarids = July 2012 
Table 2. Sources of variation in isotopes for L. benedeni and $K$. warpachowskyi from five study sites in Lake Constance and River Rhine (sampling years 2010, 2011 and 2012).

\begin{tabular}{|c|c|c|c|c|c|}
\hline Year & Source of variation & Sum of squares & df & $F$ & $P$ \\
\hline \multicolumn{6}{|l|}{2010} \\
\hline \multirow[t]{4}{*}{$\delta^{13} \mathrm{C}$} & Species & 102.14 & 1 & 26.89 & $<0.001 *$ \\
\hline & Month & 2.58 & 1 & 0.68 & 0.42 \\
\hline & Species $\times$ month & 11.79 & 1 & 3.11 & 0.09 \\
\hline & Error & 113.95 & 30 & & \\
\hline \multirow[t]{4}{*}{$\delta^{15} \mathrm{~N}$} & Species & 6.65 & 1 & 7.62 & $0.010 *$ \\
\hline & Month & 46.56 & 1 & 53.32 & $<0.001 *$ \\
\hline & Species $\times$ month & 1.74 & 1 & 1.99 & 0.17 \\
\hline & Error & 26.20 & 30 & & \\
\hline \multicolumn{6}{|l|}{2011} \\
\hline \multirow[t]{4}{*}{$\delta^{13} \mathrm{C}$} & Species & 53.96 & 1 & 10.93 & $0.004 *$ \\
\hline & Habitat & 0.36 & 1 & 0.073 & 0.79 \\
\hline & Species $\times$ habitat & 0.03 & 1 & 0.001 & 0.94 \\
\hline & Error & 88.82 & 18 & & \\
\hline \multirow[t]{4}{*}{$\delta^{15} \mathrm{~N}$} & Species & 1.13 & 1 & 7.66 & $0.013 *$ \\
\hline & Habitat & 0.65 & 1 & 4.38 & 0.052 \\
\hline & Species $\times$ habitat & 0.04 & 1 & 0.26 & 0.619 \\
\hline & Error & 2.66 & 18 & & \\
\hline \multirow[t]{4}{*}{$\delta^{34} \mathrm{~S}$} & Species & 7.40 & 1 & 36.11 & $<0.001 *$ \\
\hline & Habitat & 0.15 & 1 & 0.74 & 0.400 \\
\hline & Species $\times$ habitat & 0.004 & 1 & 0.02 & 0.895 \\
\hline & Error & 3.69 & 18 & & \\
\hline \multicolumn{6}{|l|}{2012} \\
\hline \multirow[t]{4}{*}{$\delta^{13} \mathrm{C}$} & Species & 34.62 & 1 & 26.72 & $<0.001 *$ \\
\hline & Habitat & 24.99 & 2 & 19.29 & $<0.001 *$ \\
\hline & Species $\times$ habitat & 2.82 & 2 & 2.18 & 0.156 \\
\hline & Error & 1.30 & 12 & & \\
\hline \multirow[t]{4}{*}{$\delta^{15} \mathrm{~N}$} & Species & 1.53 & 1 & 7.97 & $0.015^{*}$ \\
\hline & Habitat & 2.19 & 2 & 5.68 & $0.018 *$ \\
\hline & Species $\times$ habitat & 0.72 & 2 & 1.88 & 0.195 \\
\hline & Error & 2.31 & 12 & & \\
\hline
\end{tabular}

Bold and $*$ symbol indicate statistically significant values $(P<0.05)$.

from each of the five study sites differed significantly. In 2010, the $\delta^{15} \mathrm{~N}$ values of $L$. benedeni and $K$. warpachowskyi of the two months of March and June) also exhibited significant difference (Fig. 1 and Table 2). Mysids collected from the river Rhine in 2011 had comparable $\delta^{13} \mathrm{C}$ or $\delta^{15} \mathrm{~N}$ signatures to those collected in Lake Constance in the same year. By contrast, mysids collected from the three different lake habitats in 2012 varied significantly in terms of $\delta^{13} \mathrm{C}$ and $\delta^{15} \mathrm{~N}$ (Fig. 2 and Table 2). Briefly, the $\delta^{13} \mathrm{C}, \delta^{15} \mathrm{~N}$ and $\delta^{34} \mathrm{~S}$ values for all four species and all five study sites (in the three different study years) ranged from $-37.1 \%$ o to $-23.0 \%$, $6.3 \%$ o to $14.0 \%$ and $2.2 \%$ to $4.8 \%$, respectively, in the three different study years (see Appendix A: Fig. 1).

Applying two-way ANOVA to $\delta^{13} \mathrm{C}$ or $\delta^{15} \mathrm{~N}$ values for $D$. villosus and $G$. roeselii, revealed no significant differences between species (sampling year 2012; Table 3), but differences were apparent between habitats and in the case of $\delta^{15} \mathrm{~N}$, for the interaction of species and lake-site (Table 3). There was no significant difference between $D$. villosus and $G$. roeselii for $\delta^{13} \mathrm{C}\left(\right.$ Site 1,$\left.2010 ; t_{1,11}=-1.32, P=0.22\right)$ or $\delta^{15} \mathrm{~N}$
(Site 1,$2010 ; t_{1,11}=2.19, P=0.05$ ). The variability measure for $\delta^{13} \mathrm{C}$ distribution of each species ranges from $2 \%$ to $7 \%$. Relative coefficients of variation $(\mathrm{CV})$ in $\delta^{13} \mathrm{C}$ for L. benedeni and $K$. warpachowskyi were $7.3 \%$ and $2.1 \%$, respectively. The CV for D. villosus and G. roeselii were equivalent (4\%).

\section{Mixing models, dietary signatures and niche width}

Values of $\delta^{13} \mathrm{C}$ and $\delta^{15} \mathrm{~N}$ for periphyton and seston (obtained from indicator organisms after correcting for diettissue discrimination) are shown in Fig. 3 (shaded region). Results of the mixing models were striking, revealing that seston accounted for up to $72 \%$ of the diets of L. benedeni and that periphyton contributed a comparable proportion to $K$. warpachowskyi indicating a distinct prey specialization and clear niche partitioning in the two species of mysids (Fig. 4). 
Table 3. Sources of variation in carbon and nitrogen isotopes of D. villosus and G. roeselii from three study sites in Lake Constance.

\begin{tabular}{|c|c|c|c|c|c|}
\hline Year & Source of variation & Sum of squares & df & $F$ & $P$ \\
\hline \multicolumn{6}{|l|}{2012} \\
\hline \multirow[t]{4}{*}{$\delta^{13} \mathrm{C}$} & Species & 0.27 & 1 & 0.44 & 0.512 \\
\hline & Habitat & 86.74 & 3 & 46.80 & $<0.001 *$ \\
\hline & Species $\times$ habitat & 2.08 & 3 & 1.12 & 0.356 \\
\hline & Error & 18.54 & 30 & & \\
\hline \multirow[t]{4}{*}{$\delta^{15} \mathrm{~N}$} & Species & 0.82 & 1 & 2.25 & 0.144 \\
\hline & Habitat & 3.38 & 3 & 3.09 & $0.042 *$ \\
\hline & Species $\times$ habitat & 6.68 & 3 & 6.11 & $<0.001 *$ \\
\hline & Error & 10.94 & 30 & & \\
\hline
\end{tabular}

Bold and $*$ symbol indicate statistically significant values $(P<0.05)$.

\section{Discussion}

The four non-native species showed a wide range of $\delta^{13} \mathrm{C}, \delta^{15} \mathrm{~N}$ and $\delta^{34} \mathrm{~S}$ values, suggesting habitat differences in resource isotope signatures. Spatial differences in isotopic signatures are commonly observed between different sites in Lake Constance (e.g. Fuentes, Güde, \& Straile 2013; Matuszak, Voigt, Storch, Bauer, \& Quillfeldt 2011; Yohannes, Franke, \& Rothhaupt 2014). Interestingly however, the four species were not equally affected by inter-habitat isotopic differences [e.g., $\delta^{13} \mathrm{C}$ and $\delta^{15} \mathrm{~N}$; sampling year 2011 (Table 2) vs. $\delta^{13} \mathrm{C}$ and $\delta^{15} \mathrm{~N}$; sampling year 2012 (Table 3)].
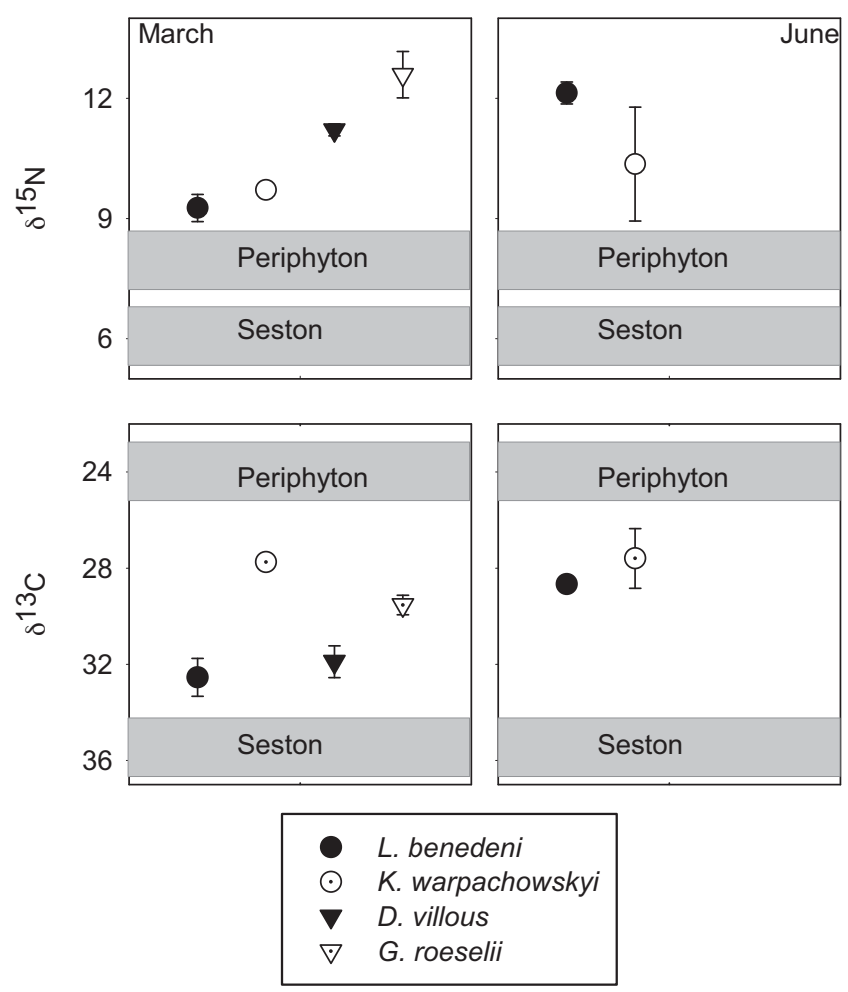

Fig. 3. Seasonal $\delta^{13} \mathrm{C}$ and $\delta^{15} \mathrm{~N}$ values \pm standard error (SE) of $L$. benedeni, K. warpachowskyi, D. villosus, G. roeselii, seston and periphyton Hard, Lake Constance (Austria): March and June, 2010.

\section{Mysids}

Comparison of samples obtained from Lake Constance and the River Rhine in 2011 and of samples from three sites in Lake Constance in 2012 (Table 2) indicate that L. benedeni and $K$. warpachowskyi conform to consistent patterns in $\delta^{13} \mathrm{C}$ and $\delta^{15} \mathrm{~N}$ (Fig. 2); and $\delta^{34} \mathrm{~S}$ (sampling year 2011, Table 2 and see Appendix A: Fig. 2). This implies that sympatric non-native mysid species feed on distinct components of the available food resource, maintaining discrete feeding niches or resource partitions irrespective of habitat (lake or river) or month (March or June, sampling year 2010, Table 2). Feeding niche differentiation can minimize interspecific competition and lead to a relatively higher species richness. In some specific locations of Lake Constance, K. warpachowskyi is estimated to comprise up to $40 \%$ of the mysid population (Hanselmann et al. 2011a, 2011b). Feeding niche differentiation may be one factor enabling this mysid to outcompete other species.

It is generally expected that $\delta^{15} \mathrm{~N}$ values will increase up the food chain, by ca. 3.4\%o from one trophic level to the next (e.g. Minagawa \& Wada 1984). Average differences in $\delta^{15} \mathrm{~N}$ between the two species of mysids studied were negligible (ca. 0.6\%o), implying similar positioning in the trophic hierarchy and reliance on food items provisioned from identical nitrogen sources (Fig. 2). In contrast to $\delta^{15} \mathrm{~N}$, mean $\delta^{13} \mathrm{C}$ and $\delta^{34} \mathrm{~S}$ values in $K$. warpachowskyi were higher (by ca. $+3 \%$ and $+1.4 \%$, respectively) than those in L. benedeni, indicating a general difference in dietary carbon and sulphur sources in the two species (Fig. 2 and Appendix A: Fig. 2).

Over all, the relative variability in $\delta^{13} \mathrm{C}$ values was significantly higher in L. benedeni (7.3\%) than in K. warpachowskyi (2.1\%), implying more generalistic feeding behavior by $L$. benedeni. The coefficients of variation (\%) in L. benedeni were more than three times higher than for K. warpachowskyi, and twice higher than for D. villosus or G. roeselii $(4 \%)$. Elsewhere, isotopic experimental isotopic study on mysids have shown that the $\delta^{13} \mathrm{C}$ and $\delta^{15} \mathrm{~N}$ values in muscles require over 12 weeks to reach an isotopic equilibrium with diet (Gorokhova \& Hansson 1999). Assuming that isotopic values of individual $L$. benedeni obtained in our study are in 
L. benedeni (March)

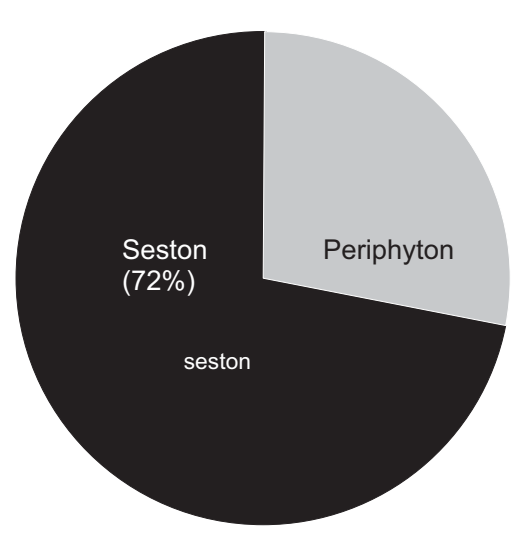

K. warpachowskyi (March)

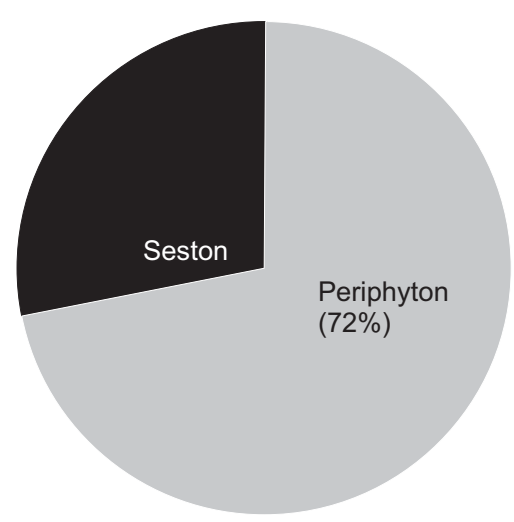

L. benedeni (June)

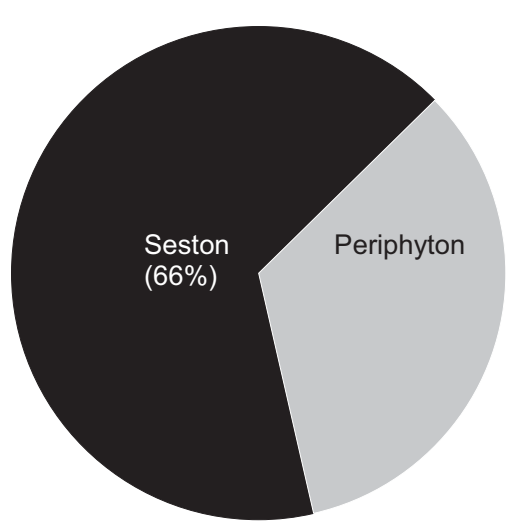

K. warpachowskyi (June)

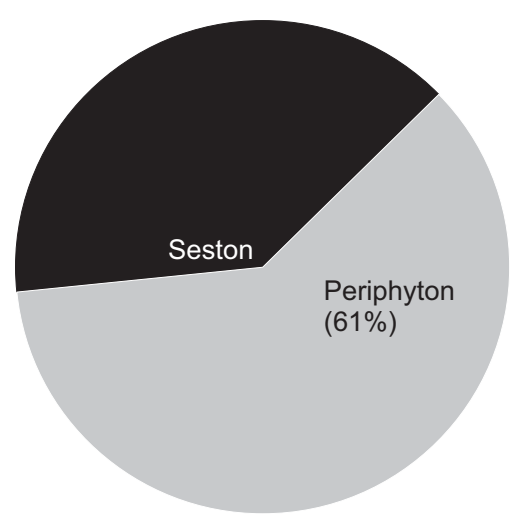

Fig. 4. Proportional estimates of seston and periphyton contributing to the diets of L. benedeni and K. warpachowskyi in March and June, 2010 .

equilibrium with their diet (and therefore individuals have acquired their isotope values over a time span of 12 weeks prior to sampling), the larger variations in isotopic values indicate an increase in individual specialization or enhanced species generalization, and thus a wider species niche width. This is in agreement with earlier studies of $L$. benedeni in Lake Constance, indicating a broad diet of organic material including algae, seston, biofilm, detritus and bio-depositions (Gergs et al. 2008; Hanselmann et al. 2013). Furthermore, the IsoError dietary mixing model confirms that seston and periphyton are the predominant contributors to tissue $\delta^{13} \mathrm{C}$ in $L$. benedeni and $K$. warpachowskyi, respectively, irrespective of season (Figs. 3 and 4).

\section{Gammarids}

Contrary to expectation, D. villosus and G. roeselii collected from the same sites (Lake Constance, sampling year 2012) exhibited no significant difference in $\delta^{13} \mathrm{C}$ and $\delta^{15} \mathrm{~N}$ (Table 3). The coefficients of variation $(\%)$ in D. villosus and $G$. roeselii were strikingly similar $(4.1 \%$, for each species). This indicates that these sympatric invaders occupy overlapping feeding sources, which might be expected to maximize interspecific competition. Interestingly however, these species display a significant inter-habitat variation in $\delta^{13} \mathrm{C}$ and $\delta^{15} \mathrm{~N}$ (Table 3, year 2012), suggesting that both $D$. villosus and $G$. roeselii are able to feed on a wide range of items, shifting their diets flexibly in response to habitat and food availability and that $D$. villosus in general is not distinctly more predacious than $G$. roeselii.

Previously, Kley and Maier (2005) showed that coexistence of predatory $D$. villosus with other invasive and native gammarids is possible by niche partitioning and at times, high habitat complexity might facilitate co-existence. In the littoral zone of Lake Constance, which is characterized by higher substrate diversity than other European lakes, these gammarids show a differentiated substrate choice. It is likely that $G$. roeselii is displaced by $D$. villosus and colonizes substrates not occupied by the latter (Hesselschwerdt, Necker, \& Wantzen 2008). Differentiated spatial niche (which may not be necessarily linked to differentiated dietary niche) might facilitate the co-existence of these two species (Kley et al. 2009). 
As the macro-invertebrate communities of different lakesites or habitats may vary in both diversity and richness, the presence or absence of direct competitors may significantly affect the quality or quantity of food a species is able to utilize. D. villosus (known as 'killer shrimp') is an extremely rapacious predator of macro-invertebrates, including other gammarids and small fishes, fish eggs and larvae. Although not all our stable isotope data supports the theory that $D$. villosus feeds on $G$. roeselii, it is interesting to note that at Site 1 , Lake Constance, $D$. villosus tissues were enriched in $\delta^{15} \mathrm{~N}$ by ca. $+2 \%$ o compared with those of G. roeselii (Fig. 2). In general, the stable isotope values $D$. villosus and $G$. roeselii indicate that the two species rely on broadly similar dietary resources. The lack of dietary partitioning could be interpreted as a consequence of superabundant food during the study period. However, if the two gammarids also share dietary sources during limited food availability, overlapping niche width (dietary breadth) coupled with voraciousness and invasive character, might exacerbate impacts on local biodiversity including the extinction of native species (reviewed by Mooney \& Cleland 2001).

Ecological mechanisms that promote the co-existence of invading species, such as dietary segregation or resource partitioning, are an important theme in ecological and evolutionary studies (e.g. Siepielski \& McPeek 2010). Our data shows that the two species of mysids and the two gammarids maintained consistent patterns of tissue isotope values, implying that $L$. benedeni and $K$. warpachowskyi occupy significantly differentiated feeding niches while $D$. villosus and $G$. roeselii exhibit minimal dietary segregation, appearing to exist within widely overlapping feeding niches. Lack of segregation in the gammarids might enhance interspecific competition, except during periods of food abundance.

Based on the current study alone however, it is difficult to conclude to what extent niche differentiation or overlap might be inherent characteristics or lead by extrinsic factors such as active competition between cohabiting invaders of a relatively 'new' environment. If dietary niche is purely extrinsically driven, it might describe current dietary variation while telling us little about fundamental or fixed differences in dietary preferences. Dietary segregations or overlaps can have both dynamic and static phases depending on spatiotemporal patterns of resource availability and on the diversity and richness of co-existing competitors and predators.

Based on the isotopic results, dietary signatures, and a mixing model, we conclude that dietary segregation might enable the coexistence of the mysids and could boost their success by reducing direct competition for resources. Considering the aggressive and voracious feeding behavior of the two gammarid species, co-invasion might have serious impacts on local species diversity, including the possible extinction of Lake Constance natives. L. benedeni and $K$. warpachowskyi are able to reach up to five generations per year, attain maturation in relatively short time and exhibit a longer reproductive period (Borza 2014). These characteristics might increase invasion success and alter community structure of invaded habitats.

There are several dramatic real-time examples showing how interactions between non-native and native biota can result in unexpected but persistent outcomes, altering community and ecosystem structures and resulting in the extinction of native species (e.g., Ricciardi, Neves, \& Rasmussen 1998; Ricciardi \& Rasmussen 1999; Worthington \& Lowe-McConnell 1994). It is not always possible to prevent the introduction of new species, but systematic research undoubtedly holds the key to improving understanding the ecology of invasive aliens and their likely impacts. Routine monitoring is clearly essential if new biotas are to be detected in time to allow a sufficiently rapid response. Data on niche width, species specialization and dietary segregation of invasive species have important ecological, evolutionary and conservation implications.

\section{Acknowledgments}

We appreciate the help of Christian Fiek, Katharina Greiner-Perth, Eva-Maria Engesser, Birgit Beck and Saskia Rehse during sample collection, preparation and analysis. We thank three anonymous reviewers for valuable comments and suggestions. The study was supported by the "Umwelt und Wohnen an der Universität Konstanz" and Start up grant (Young Scholar fund) of the University of Konstanz to EY.

\section{Appendix A. Supplementary data}

Supplementary material related to this article can be found, in the online version, at http://dx.doi.org/10.1016/ j.baae.2014.07.002.

\section{References}

Audzijonyte, A., Wittmann, K., Ovcarenko, I., \& Väinölä, R. (2009). The Ponto-Caspian crustacean Limnomysis benedeni dispersing across Europe. Diversity and Distributions, 15, 346-355.

Bearhop, S., Adams, C. E., Waldron, S., Fuller, R. A., \& Macleod, H. (2004). Determining trophic niche width: A novel approach using stable isotope analysis. Journal of Animal Ecology, 73, 1007-1012.

Bij De Vaate, A., Jazdzewski, K., Ketelaars, H. A. M., Gollasch, S., \& Van Der Velde, G. (2002). Geographical patterns in range extension of Ponto-Caspian macroinvertebrate species in Europe. Canadian Journal of Fisheries and Aquatic Sciences, 59, 1159-1174.

Borza, P. (2014). Life history of invasive Ponto-Caspian mysids (Crustacea: Mysida): A comparative study. Limnologica, 44, 9-17.

Chesson, P. (2000). Mechanisms of maintenance of species diversity. Annual Review of Ecology and Systematics, 31, 343-366.

Dediu, I. I. (1966). Répartition et caractéristi que écoloque des Mycides des bassins des rivièrs Dniestr et Pruth. Revue roumaine de Biologie: Serie de Zoologie, 11, 239. 
Dick, J. T. A., \& Platvoet, D. (2000). Invading predatory crustacean Dikerogammarus villosus eliminates both native and exotic species. Proceedings of the Royal Society B, 267, 977-983.

Fink, P., \& Harrod, C. (2013). Carbon and nitrogen stable isotopes reveal use of pelagic resources by the invasive Ponto-Caspian Mysid Limnomysis benedeni. Isotopes in Environmental and Health Studies, 49, 312-317.

Finlay, J. C., \& Kendall, C. (2007). Stable isotope tracing of temporal and spatial variability in organic matter sources to freshwater ecosystems. In R. H. Michener, \& K. Lajtha (Eds.), Stable isotopes in ecology and environmental science (2nd ed., pp. 283-333). MA, Oxford, Victoria: Blackwell Publishing.

France, L. R. (1995). Differentiation between littoral and pelagic food webs in lakes using stable carbon isotopes. Limnology \& Oceanography, 40, 1310-1313.

Fritz, B., Nisch, A., Wittkugel, C., \& Mörtl, M. (2006). Erstnachweis von Limnomysis benedeni Czerniavsky im Bodensee (Crustacea: Mysidacea). Lauterbornia, 58, 157-160.

Fuentes, N., Güde, H., \& Straile, D. (2013). Importance of allochthonous carbon supply for profundal macrozoobenthic communities in a deep oligotrophic lake. International Review of Hydrobiology, 98, 1-13.

Gergs, R., Hanselmann, A. J., Eisele, I., \& Rothhaupt, K.-O. (2008). Autecology of Limnomysis benedeni Czerniavsky, 1882 (Crustacea: Mysida) in Lake Constance, Southwestern Germany. Limnologica, 38, 139-146.

Gergs, R., \& Rothhaupt, K.-O. (2008). Feeding rates, assimilation efficiencies and growth of two amphipod species on biodeposited material from zebra mussels. Freshwater Biology, 53, 2494-2503.

Gorokhova, E., \& Hansson, S. (1999). An experimental study on variations in stable carbon and nitrogen isotopes fractionation during growth of Mysis mixta and Neomysis integer. Canadian Journal of Fisheries and Aquatic Sciences, 56, 2203-2210.

Grabowski, M., Bacela, B., \& Konopacka, A. (2007). How to be an invasive gammarid (Amphipoda: Gammaroidea) - Comparison of life history traits. Hydrobiologia, 590, 75-84.

Hanselmann, A. J. (2010). Katamysis warpachowskyi Sars, 1877 (Crustacea, Mysida) invaded Lake Constance. Aquatic Invasions, 5, 31-34.

Hanselmann, A. J., Gergs, R., \& Rothhaupt, K.-O. (2011a). Embryonic development time of the freshwater mysid Limnomysis benedeni Czerniavsky as a function of water temperature. Aquatic Ecology, 45, 539-546.

Hanselmann, A. J., Gergs, R., \& Rothhaupt, K.-O. (2011b). Seasonal shifts in the life cycle of the ponto-caspian invader Limnomysis benedeni (Crustacea: Mysida): A physiological adaptation? Hydrobiologia, 673, 193-204.

Hanselmann, A. J., Hodapp, B., \& Rothhaupt, K.-O. (2013). Nutritional ecology of the invasive freshwater mysid Limnomysis benedeni: Field data and laboratory experiments on food choice and juvenile growth. Hydrobiologia, 705, 75-86.

Hartmann, J. (1977). Die Trüsche (Lota lota) im eutrophierten Bodensee. Archiv für Hydrobiologie, 80, 360-374.

Hesselschwerdt, J., Necker, J., \& Wantzen, M. K. (2008). Gammarids in Lake Constance: habitat segregation between the invasive Dikerogammarus villosus and the indigenous Gammarus roeselii. Fundamental \& Applied Limnology, 173, 177-186.

Hofmann, H., Lorke, A., \& Peeters, F. (2011). Wind and ship wave-induced resuspension in the littoral zone of a large lake. Water Resources Research, 47, W09505. http://dx.doi.org/ 10.1029/2010WR010012

Kiefer, F. (1972). Naturkunde des Bodensees (2nd ed.). Thorbecke: Lindau and Konstanz.

Kinzler, W., Kley, A., Mayer, G., Waloszek, D., \& Maier, G. (2009). Mutual predation between and cannibalism within several freshwater gammarids: Dikerogammarus villosus versus one native and three invasives. Aquatic Ecology, 43, 457-464.

Kinzler, W., \& Maier, G. (2003). Asymmetry in mutual predation: Possible reason for the replacement of native gammarids by invasives. Archiv für Hydrobiologie, 157, 473-481.

Kley, A., Kinzler, W., Schank, Y., Mayer, G., Waloszek, D., \& Maier, G. (2009). Influence of substrate preference and complexity on co-existence of two non-native gammarideans (Crustacea: Amphipoda). Aquatic Ecology, 43, 1047-1059.

Kley, A., \& Maier, G. (2005). An example of niche partitioning between Dikerogammarus villosus and other invasive and native gammarids: A field study. Journal of Limnology, 64, $85-88$.

Kling, G. W., Fry, B., \& O’Brien, W. J. (1992). Stable isotopes and planktonic trophic structure in arctic lakes. Ecology, 73, 561-566.

Kotler, B. P., Brown, J. S., \& Subach, A. (1993). Mechanisms of species coexistence of optimal foragers: Temporal partitioning by two species of sand dune gerbils. Oikos, 67, 548-556.

Leyequién, E., de Boer, W. F., \& Cleef, A. (2007). Influence of body size on coexistence of bird species. Ecological Research, 22, 735-741.

MacNeil, C., Dick, J. T. A., Hatcher, M. J., Terry, R. S., Smith, J. E., \& Dunn, A. M. (2003). Parasites mediate mutual predation between native and invasive species. Proceedings of the Royal Society B, 270, 1309-1314.

MacNeil, C., Dick, J. T. A., Platvoet, D., \& Briffa, M. (2011). Direct and indirect effects of species displacements; the invading amphipod crustacean Dikerogammarus villosus can disrupt aquatic ecosystem energy flow and function. Journal of the North American Benthological Society, 30, 38-48.

Matuszak, A., Voigt, C., Storch, I., Bauer, H.-G., \& Quillfeldt, P. (2011). Depth-specific and spatiotemporal variation of $\delta^{13} \mathrm{C}$ and $\delta^{15} \mathrm{~N}$ in Charophytes of Lake Constance: Implications for food web studies. Rapid Communications in Mass Spectrometry, 25, 2089-2094.

Minagawa, M., \& Wada, E. (1984). Stepwise enrichment of ${ }^{15} \mathrm{~N}$ along food chains: Further evidence and the relation between ${ }^{15} \mathrm{~N}$ and animal age. Geochimica et Cosmochimica Acta, 48, $1135-1140$.

Mooney, H. A., \& Cleland, E. E. (2001). The evolutionary impact of invasive species. Proceedings of the National Academy of Sciences of the United States of America, 20, 5446-5451.

Mürle, U., Becker, A., \& Rey, P. (2004). Dikerogammarus villosus (Amphipoda) im Bodensee. Lauterbornia, 49, 77-79.

Newsome, S. D., Tinker, M. T., Monson, D. H., Oftedal, O. T., Ralls, K., Staedler, M. M., et al. (2009). Using stable isotopes to investigate individual diet specialization in California sea otters (Enhydra lutris nereis). Ecology, 90, 961-974.

Page, B., McKenzie, J., \& Goldsworthy, S. D. (2005). Dietary resource partitioning among sympatric New Zealand and Australian fur seals. Marine Ecology Progress Series, 293, 283-302. 
Peters, L., Scheifhacken, N., Kahlert, M., \& Rothhaupt, K.-O. (2005). An efficient in situ method for sampling periphyton in lakes and streams. Archiv für Hydrobiologie, 163, 133-141.

Peterson, B. J., \& Fry, B. (1987). Stable isotopes in ecosystem studies. Annual Review of Ecology and Systematics, 18, 293-320.

Philips, D. (2012). Converting isotope values to diet composition: The use of mixing models. Journal of Mammalogy, 93, 342-352.

Philips, D., \& Gregg, J. W. (2003). Source partitioning using stable isotopes: Coping with too many sources. Oecologia, 136, 261-269.

Post, D. M. (2002). Using stable isotopes to estimate trophic position: Models, methods, and assumptions. Ecology, 83, 703-718.

Richards, M. P., Fuller, B. T., Sponheimer, M., Robinson, T., \& Ayliffe, L. (2003). Sulphur isotopes in palaeodietary studies: A review and results from a controlled feeding experiment. International Journal of Osteoarchaeology, 13, 37-45.

Ricciardi, A., Neves, R. J., \& Rasmussen, J. B.(1998).Impending extinctions of North American freshwater mussels (Unionoida) following the zebra mussel (Dreissena polymorpha) invasion. Journal of Animal Ecology, 67, 613-619.
Ricciardi, A., \& Rasmussen, J. B. (1999). Extinction rates of North American freshwater Fauna. Conservation Biology, 13, 1220-1222.

Siepielski, A. M., \& McPeek, M. A. (2010). On the evidence for species coexistence: A critique of the coexistence program. Ecology, 91, 3153-3164.

Worthington, E. B., \& Lowe-McConnell, R. (1994). African lakes reviewed: Creation and destruction of biodiversity. Environmental Conservation, 21, 199-213.

Yohannes, E., Franke, L., \& Rothhaupt, K.-O. (2014). Zebra mussel $\delta^{13} \mathrm{C}$ and $\delta^{15} \mathrm{~N}$ as a proxy for depth-specific pelagic isotope profiles and lake temperature. Hydrobiologia, 731, 191-198. 


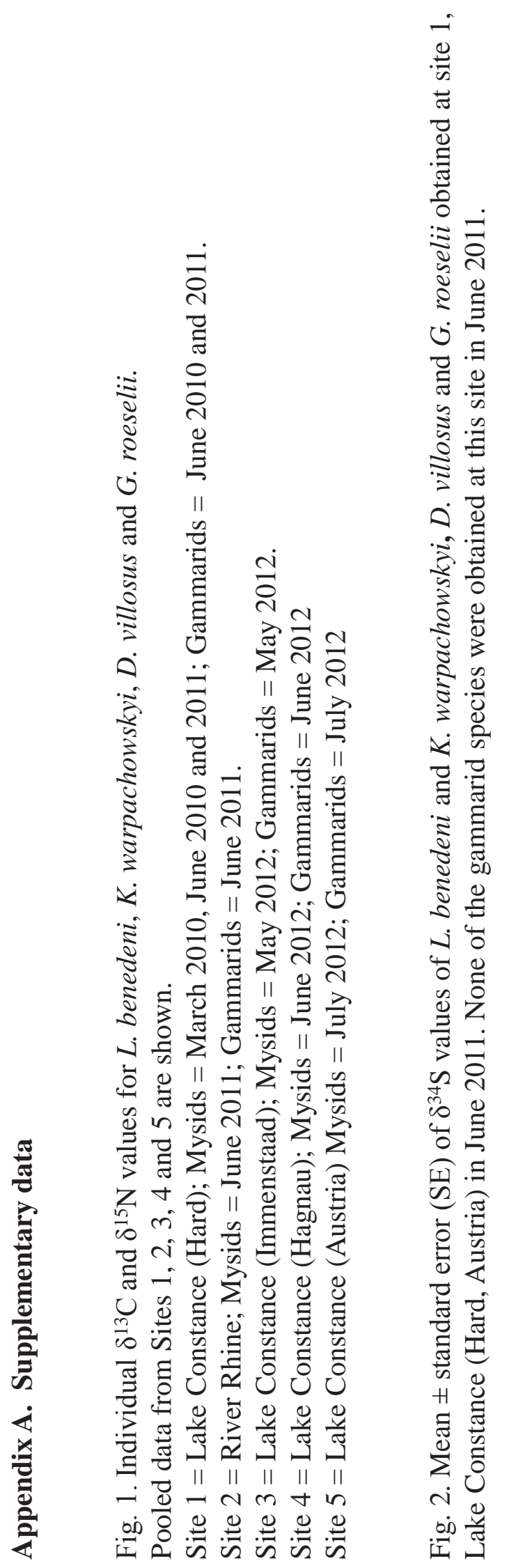




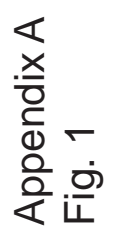

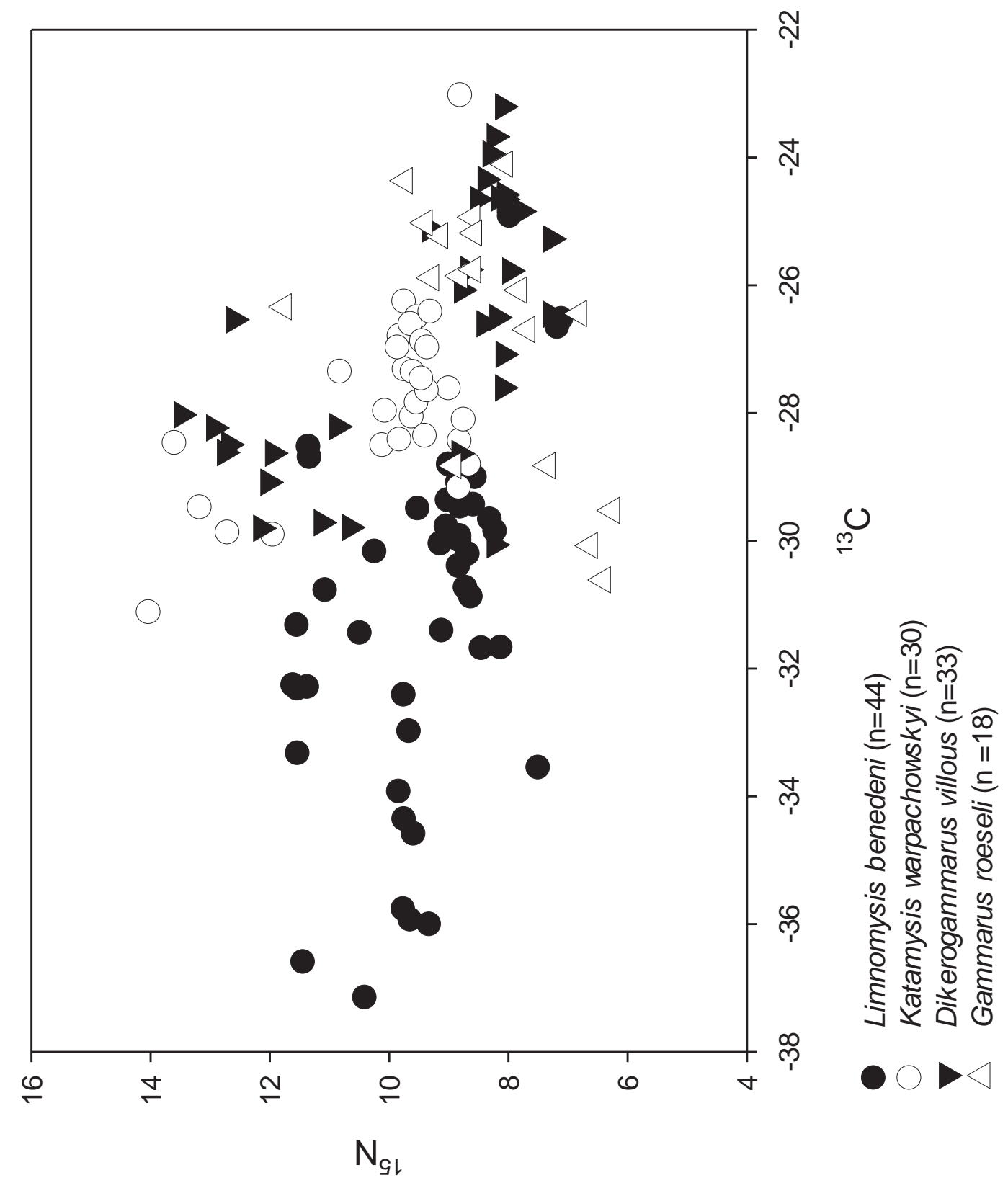



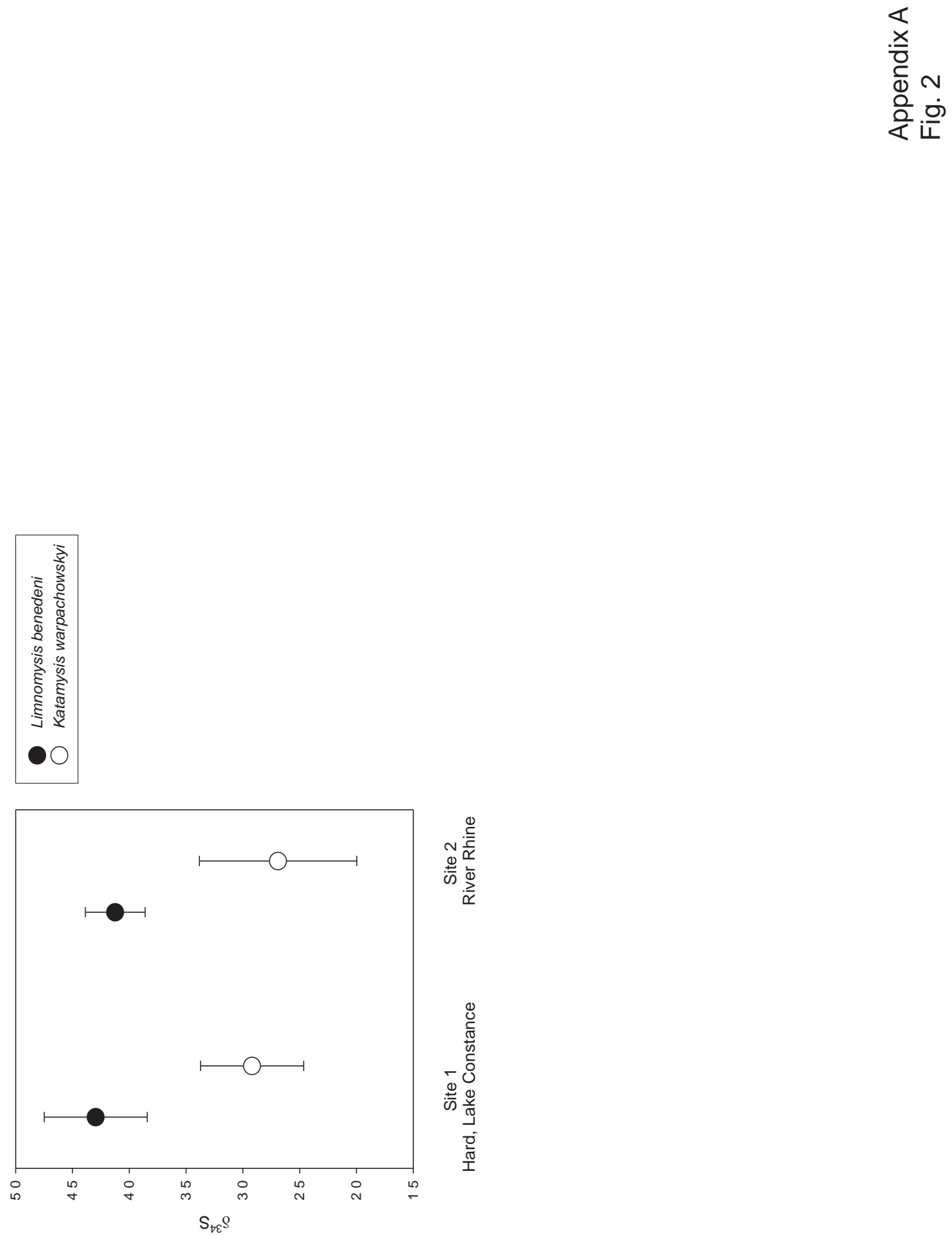